\title{
Differential effects of ozone on photosynthesis of winter wheat among cultivars depend on antioxidative enzymes rather than stomatal conductance
}

\author{
Zhaozhong Feng a,b,*, Liang Wang ${ }^{a}$, Håkan Pleijel ${ }^{c}$, Jianguo Zhu ${ }^{d}$, Kazuhiko Kobayashi ${ }^{\mathrm{b}}$

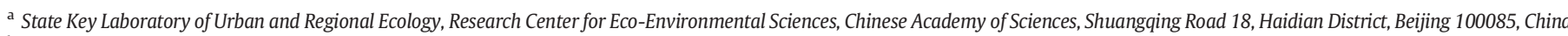 \\ b Graduate School of Agricultural and Life Sciences, The University of Tokyo, 1-1-1 Yayoi, Bunkyo-ku, Tokyo 113-8657, Japan

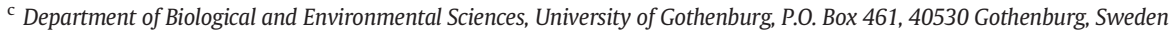 \\ d State Key Laboratory of Soil and Sustainable Agriculture, Institute of Soil Sciences, Chinese Academy of Sciences, Nanjing 210008, China
}

\section{H I G H L I G H T S}

- 5 modern cultivars of wheat were investigated under fully open-air field conditions.

- Significant $\mathrm{O}_{3}$ effects were only found during the mid-grain filling stage.

- The lower photosynthetic rates were mainly due to nonstomatal factors.

- Antioxidative enzymes contributed to the differential response to $\mathrm{E}_{-} \mathrm{O}_{3}$ among cultivars.

\section{G R A P H I C A L A B S T R A C T}

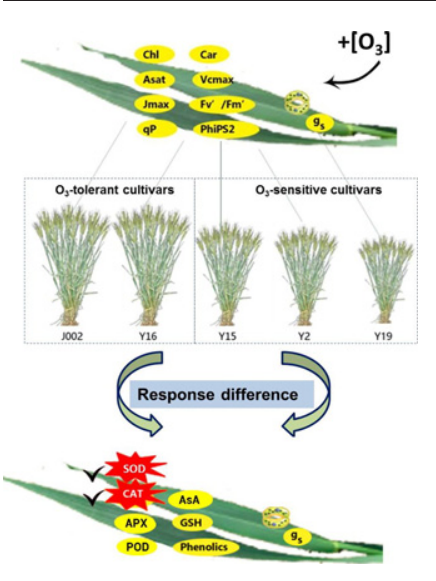

A B S T R A C T

Five modern cultivars of winter wheat (Triticum aestivum L.): Yangmai16 (Y16), Yangmai 15 (Y15), Yangfumai 2 (Y2), Yannong 19 (Y19) and Jiaxing 002 (J2) were investigated to determine the impacts of elevated ozone concentration $\left(\mathrm{E}-\mathrm{O}_{3}\right)$ on photosynthesis-related parameters and the antioxidant system under fully open-air field conditions in China. The plants were exposed to $\mathrm{E}-\mathrm{O}_{3}$ at 1.5 times the ambient ozone concentration $\left(\mathrm{A}-\mathrm{O}_{3}\right)$ from the initiation of tillering to final harvest. Pigments, gas exchange rates, chlorophyll $a$ fluorescence, antioxidants contents, antioxidative enzyme activity and lipid oxidation were measured in three replicated plots throughout flag leaf development. Results showed that significant $\mathrm{O}_{3}$ effects on most variables were only found during the mid-grain filling stage. Across five cultivars, $\mathrm{E}-\mathrm{O}_{3}$ significantly accelerated leaf senescence, as indicated by increased lipid oxidation as well as faster declines in pigment amounts and photosynthetic rates. The lower photosynthetic rates were mainly due to non-stomatal factors, e.g. lower maximum carboxylation capacity and electron transport rates. There were strong interactions between $\mathrm{O}_{3}$ and cultivar in photosynthetic pigments, light-saturated photosynthesis rate and chlorophyll a fluorescence with $\mathrm{O}_{3}$-sensitive (Y19, Y2 and Y15) and $\mathrm{O}_{3}$-tolerant $(\mathrm{J} 2, \mathrm{Y} 16)$ cultivars being clearly differentiated in their responses to $\mathrm{E}-\mathrm{O}_{3}$. $\mathrm{E}-\mathrm{O}_{3}$ significantly influenced the antioxidative enzymes but not antioxidant contents. Significant interactions between $\mathrm{O}_{3}$ and

\footnotetext{
* Corresponding author at: Shuangqing Road 18, Haidian District, Beijing 100085, China.

E-mail address: fzz@rcees.ac.cn (Z. Feng).
} 
cultivar were found in antioxidative enzymes, such as SOD and CAT, but not in stomatal conductance $\left(g_{\mathrm{s}}\right)$. Therefore, it can be concluded that antioxidative enzymes rather than $g_{s}$ or antioxidants are responsible for the differential responses to $\mathrm{E}_{-} \mathrm{O}_{3}$ among cultivars. These findings provide important information for the development of accurate modeling $\mathrm{O}_{3}$ effects on crops, especially with respect to the developmental stage when $\mathrm{O}_{3}$ damage to photosynthesis becomes manifest.

(c) 2016 Elsevier B.V. All rights reserved.

\section{Introduction}

Ground-level ozone $\left(\mathrm{O}_{3}\right)$ is the most important phytotoxic air pollutant at global scale with adverse impacts on terrestrial vegetation (Ashmore, 2005; Booker et al., 2009; Bytnerowicz et al., 2007; Feng and Kobayashi, 2009; Feng et al., 2014, 2015; Van Dingenen et al., 2009). A meta-analysis based on numerous chamber studies revealed that elevated $\mathrm{O}_{3}$ concentration (average $73 \mathrm{ppb}$ ) reduced leaf photosynthesis and grain yield of wheat by $20 \%$ and $29 \%$, respectively, as compared with plants grown in carbon-filtered air (Feng et al., 2008). The grain filling period is the most sensitive developmental period to $\mathrm{O}_{3}$, during which the decreased photosynthesis induced by elevated $\mathrm{O}_{3}$ concentration appears to be the key driver for the yield loss (Gelang et al., 2000; Pleijel et al., 1998). Although the photosynthetic rate in saturating light $\left(A_{\text {sat }}\right)$ is often co-limited by stomatal and biochemical factors under field conditions, many scientists argued that the central biochemical process rather than the stomatal limitation $\left(L_{s}\right)$ of $A_{\text {sat }}$ was the main cause for the $\mathrm{O}_{3}$-induced reduction in photosynthesis (Farage and Long, 1999; Feng et al., 2011; Fiscus et al., 1997; Morgan et al., 2004; Zheng et al., 2002). Among the non-stomatal factors, maximum carboxylation $\left(V_{\mathrm{cmax}}\right)$, reflecting in vivo Rubisco activity, as well as the maximum rate of RuBP regeneration $\left(J_{\max }\right)$ have been reported to play the most important role (Farage and Long, 1999; Fiscus et al., 2005; Morgan et al., 2004; Sun et al., 2014). Other important physiological responses reported to be affected by $\mathrm{O}_{3}$ include the changes in chlorophyll $a$ fluorescence variables such as reduction in quenching of photochemical efficiency ( $q \mathrm{P}$ ) and quantum yield of PSII in the light (PhiPS2) (Feng et al., 2011), as well as endogenous antioxidant metabolism (Inada et al., 2012).

Many studies have been done to clarify the mechanism of plant defense to $\mathrm{O}_{3}$ damage in relation to detoxification of reactive oxygen species (ROS) (Dizengremel et al., 2008; Paoletti et al., 2008), and reported that the responses of antioxidant metabolism varied by species/ cultivars, depending on the concentrations of $\mathrm{O}_{3}$ and the duration of the fumigation, e.g. acute vs. chronic ozone exposure (Baier et al., 2005; Betzelberger et al., 2010; Burkey et al., 2003; Feng et al., 2011; Kollist et al., 2000; Wang et al., 2014a, 2014b). In general, acute exposure to relatively high $\mathrm{O}_{3}$ concentrations often caused leaf lesions resulting from programmed cell death associated with plant-pathogen

Table 1

ANOVA results for the photosynthesis related parameters measured across the measurements at heading, flowering, early-grain filling, and mid-grain filling stages.

\begin{tabular}{|c|c|c|c|c|c|c|}
\hline Variables & $\mathrm{O}_{3}$ & Cultivar (C) & Date (D) & $\mathrm{O}_{3}{ }^{*} \mathrm{C}$ & $\mathrm{O}_{3}{ }^{*} \mathrm{D}$ & $\mathrm{O}_{3}{ }^{*} \mathrm{C} * \mathrm{D}$ \\
\hline$A_{\text {sat }}$ & 0.293 & 0.017 & $<0.001$ & 0.546 & $<0.001$ & 0.001 \\
\hline $\mathrm{Ci}$ & 0.720 & 0.041 & $<0.001$ & 0.369 & $<0.001$ & $<0.001$ \\
\hline$g_{s}$ & 0.395 & 0.061 & $<0.001$ & 0.383 & 0.001 & 0.171 \\
\hline$V_{\mathrm{cmax}}$ & 0.986 & 0.001 & $<0.001$ & 0.601 & $<0.001$ & $<0.001$ \\
\hline$J_{\max }$ & 0.478 & $<0.001$ & $<0.001$ & 0.661 & $<0.001$ & 0.003 \\
\hline$L_{\mathrm{S}}$ & 0.609 & 0.005 & $<0.001$ & 0.089 & $<0.001$ & 0.041 \\
\hline$V_{\mathrm{cmax}} / J_{\max }$ & 0.616 & 0.012 & 0.001 & 0.456 & $<0.001$ & $<0.001$ \\
\hline $\mathrm{Fv}^{\prime} / \mathrm{Fm}^{\prime}$ & 0.128 & 0.054 & $<0.001$ & 0.916 & $<0.001$ & 0.001 \\
\hline PhiPS2 & 0.260 & 0.003 & $<0.001$ & 0.226 & $<0.001$ & 0.003 \\
\hline $\mathrm{PhiCO}_{2}$ & 0.129 & 0.901 & $<0.001$ & 0.624 & $<0.001$ & $<0.001$ \\
\hline$q \mathrm{P}$ & 0.651 & 0.002 & $<0.001$ & 0.144 & $<0.001$ & 0.003 \\
\hline Chl & 0.695 & 0.154 & $<0.001$ & 0.803 & $<0.001$ & $<0.001$ \\
\hline Car & 0.852 & 0.447 & $<0.001$ & 0.993 & $<0.001$ & 0.007 \\
\hline
\end{tabular}

interaction (Kangasjarvi et al., 2005; Overmyer et al., 2003; Rao et al., 2000 ) and induces an increase in antioxidant metabolism (Conklin and Barth, 2004; Kangasjarvi et al., 1994). The chronic exposure to relatively low $\mathrm{O}_{3}$ concentrations always induces declined photosynthesis along with accelerated leaf senescence and consequently reductions in productivity and yield (Ashmore, 2005; Burkart et al., 2013; Feng and Kobayashi, 2009; Feng et al., 2008; Feng et al., 2011; Zhu et al., 2011). Recent evidence showed an increased total antioxidant capacity of soybean plants when chronically exposed to the elevated $\mathrm{O}_{3}$ concentration (Gillespie et al., 2011, 2012). These authors also suggested that the antioxidant metabolism was primed by previous exposure to oxidative stress, indicating the importance of the endogenous antioxidant metabolism in detoxifying ROS. However, the results from soybean plants contrast with earlier studies conducted in wheat in $\mathrm{O}_{3}$-FACE platform with two cultivars, which generally showed a declining trend of antioxidant pools and key enzymes in the apoplast and leaf tissues under $\mathrm{O}_{3}$ stress (Feng et al., 2010; Wang et al., 2014a, 2014b).

In the present study, therefore, we examined the photosynthetic potential and antioxidant metabolism in the leaf tissues among five wheat cultivars in order to determine whether there are different responses to $\mathrm{O}_{3}$ among cultivars, and if so, which factors contribute to the differences. To this aim, we re-examined part of the data set presented in Feng et al. (2011) and compared them with new data obtained under the same experimental conditions.

\section{Materials and methods}

\subsection{Experiment site}

The fully open-air $\mathrm{O}_{3}$ fumigation system $\left(\mathrm{O}_{3}\right.$-FACE) is located in a paddy field in Xiaoji Town, Jiangsu Province, China $\left(119^{\circ} 42^{\prime} \mathrm{E}, 32^{\circ} 35^{\prime} \mathrm{N}\right)$ with continuous rice/wheat or rice/rapeseed rotation for $>1000$ years. The soil is Shajiang Aquic Cambisols with a sandy-loamy texture. The site belongs to the subtropical marine climatic zone with mean annual precipitation and mean annual temperature being $1100-1200 \mathrm{~mm}$ and $16^{\circ} \mathrm{C}$, respectively. Total annual sunshine hour is $>2000 \mathrm{~h}$ and frost-free period $>230$ days. During the growth period from 1st March (around turning green stage) to final harvest in this study, mean daily maximum and minimum temperature were 20.6 and $10.1^{\circ} \mathrm{C}$, respectively. Mean daily maximum photosynthetic photon flux density (PPFD) was $1376 \mathrm{mmolm}^{-2} \mathrm{~s}^{-1}$ and accumulated precipitation was $171 \mathrm{~mm}$.

Table 2

ANOVA results for the antioxidant-related parameters across the measurements at flowering and mid-grain filling stages.

\begin{tabular}{lllllll}
\hline Variables & $\mathrm{O}_{3}$ & Cultivar $(\mathrm{C})$ & Date $(\mathrm{D})$ & $\mathrm{O}_{3}{ }^{*} \mathrm{C}$ & $\mathrm{O}_{3}{ }^{*} \mathrm{D}$ & $\mathrm{O}_{3}{ }^{*} \mathrm{C}{ }^{*} \mathrm{D}$ \\
\hline APX & 0.351 & 0.010 & 0.001 & 0.335 & 0.035 & 0.319 \\
POD & 0.471 & $<0.001$ & 0.001 & 0.891 & 0.839 & 0.497 \\
CAT & 0.917 & 0.177 & $<0.001$ & 0.471 & 0.005 & $<0.001$ \\
SOD & 0.978 & $<0.001$ & $<0.001$ & 0.666 & 0.084 & 0.049 \\
GSH & 0.981 & 0.013 & 0.006 & 0.261 & 0.697 & 0.248 \\
Phenolics & 0.684 & 0.002 & $<0.001$ & 0.379 & 0.375 & 0.032 \\
MDA & 0.537 & 0.552 & $<0.001$ & 0.931 & $<0.001$ & 0.038 \\
AsA & 0.100 & $<0.001$ & $<0.001$ & 0.537 & $<0.001$ & 0.430
\end{tabular}




\subsection{Plant material}

Five modern cultivars i.e. Yannong 19 (Y19), Yangmai 16 (Y16), Yangmai 15 (Y15) and Yangfumai 2 (Y2), and Jiaxing 002 (J2) were selected for the comparison in the 2007/2008 growing season. The cultivation followed the standard local practices (Zhu et al., 2011). All wheat seeds were sown on 13 November 2007. The N fertilizer was applied as urea and diammonium phosphate with the total amount being $210 \mathrm{~kg} \mathrm{~N} \mathrm{ha}^{-1}$, of which $60 \%$ was applied at planting, $10 \%$ at early tillering and 30\% at elongation stage. The $\mathrm{P}$ and $\mathrm{K}$ fertilizers were applied at the total amount of $90 \mathrm{~kg} \mathrm{P}_{2} \mathrm{O}_{5} \mathrm{ha}^{-1}$ and $90 \mathrm{~kg} \mathrm{~K}_{2} \mathrm{O} \mathrm{ha}{ }^{-1}$, respectively, of which $60 \%$ was applied at planting and $40 \%$ at elongation stage. No irrigation was applied during the experiment due to subtropical climate with sufficient rainfall.

\subsection{Fumigation treatment}

Two $\mathrm{O}_{3}$ treatments were ambient $\left(\mathrm{A}-\mathrm{O}_{3}\right)$ and elevated $\left(\mathrm{E}-\mathrm{O}_{3}\right) \mathrm{O}_{3}$ concentration $\left(\left[\mathrm{O}_{3}\right]\right)$, and the targeted concentration in $\mathrm{E}-\mathrm{O}_{3}$ was 1.5 times ambient $\left[\mathrm{O}_{3}\right]$. Wheat plants were grown in three replicate rings $\left(240 \mathrm{~m}^{2}\right)$ for each treatment. $\mathrm{O}_{3}$ addition started on 5 March 2008, when wheat plants were at tillering stage, and continued until the grain maturity. The daily fumigation period was from 9:00 h to sunset, when ambient $\left[\mathrm{O}_{3}\right]$ was below $20 \mathrm{ppb}$. More details of the design and the performance of the $\mathrm{O}_{3}$-FACE are available elsewhere (Feng et al., 2011; Tang et al., 2011). During the study, M7 (9:00-16:00) in A- $\mathrm{O}_{3}$ averaged $52 \mathrm{ppb}$ with a maximum of $110 \mathrm{ppb}$. The observed maximum ambient $1 \mathrm{~h}$ mean $\left[\mathrm{O}_{3}\right]$ was $140 \mathrm{ppb}$ in one afternoon, suggesting a serious $\mathrm{O}_{3}$ pollution in this region of China (Feng et al., 2011).

\subsection{Plant sampling}

Plant samples for biochemical assay of antioxidant system were taken twice during flowering and mid-grain filling stages. For each ring, six plants of each cultivar were randomly selected and divided into three groups on each sampling occasion. Fully expanded flag leaves of each plant were punched quickly and then immersed in liquid $\mathrm{N}_{2}$. The leaf samples were stored at $-80^{\circ} \mathrm{C}$ until further biochemical analysis. The measurements of gas exchange and chlorophyll $a$ fluorescence were carried out at four developmental stages: heading, flowering, early- and mid- grain fillings.

\subsection{Biochemical assay of antioxidant system in leaf tissues}

Frozen leaf tissues were ground into powder in liquid $\mathrm{N}_{2}$ with a mortar and a pestle for the biochemical assay. Ascorbic acid (AsA) contents were measured by monitoring the changes of absorbance at $265 \mathrm{~nm}$ (an extinction coefficient of $14 \mathrm{mM}^{-1} \mathrm{~cm}^{-1}$ ) after addition of ascorbate oxidase (Luwe and Heber, 1995). Glutathione (GSH) content was measured with a 5,5'-dithio-bis-2-nitrobenzoic acid (DTNB)-glutathione disulfide reductase recycling assay following the method of Griffith (1980). The content of total phenols was determined by a FolinCiocalteu assay according to the method of Singleton and Rossi (1965) using gallic acid as a standard. Malondialdehyde (MDA) content was assessed for estimation of lipid peroxidation by 2-thiobarbituric acid-reactive metabolite (TBA) according to the method of Heath and Packer (1968) and calculated by the equation of $\mathrm{C}_{\mathrm{MDA}}\left(\mathrm{mmol} \mathrm{L}^{-1}\right)=$ $6.45 *($ A532 - A600 $)-0.56 *$ A450 in order to rule out the disturbances from nonspecific (A600) and sugar (A450) absorbance. All measurements were conducted by microplate reader (SPECTRA MAX 190, MD Com. USA).

For antioxidant enzymes: two leaflets were extracted using $2 \mathrm{ml}$ of $50 \mathrm{mM}$ sodium phosphatebuffer ( $\mathrm{pH} 7.0$, containing $1 \%$ vinyl pyrrolidone). The samples were centrifuged at $15,000 \mathrm{r} \mathrm{min}^{-1}$ for $15 \mathrm{~min}$ and the supernatant was collected at $4{ }^{\circ} \mathrm{C}$. The activities of antioxidant enzymes of superoxide dismutase (SOD), peroxidases (POD) and ascorbate peroxidase (APX) were determined following the description by Wang et al. (2014a). The SOD activity was determined by estimating its ability of inhibiting the photochemical reduction of nitro blue tetrazolium (NBT) and the absorbance was read at $560 \mathrm{~nm}$. The amount of enzyme that inhibited the 50\% NBT reduction was defined as one unit of SOD activity. The POD activity was measured by monitoring the changes of the absorbance at $470 \mathrm{~nm}$ (an extinction coefficient of $26.6 \mathrm{mM}^{-1} \mathrm{~cm}^{-1}$ ) after the enzyme extract was mixed with a $50 \mathrm{mM}$ phosphate buffer ( $\mathrm{pH}$ 6.0) containing $1 \mathrm{mM}$ guaiacol and $0.5 \mathrm{mM}$ $\mathrm{H}_{2} \mathrm{O}_{2}$. The APX activity was assayed by monitoring the change of the absorbance at $290 \mathrm{~nm}$ (an extinction coefficient of $2.8 \mathrm{mM}^{-1} \mathrm{~cm}^{-1}$ ) after the enzyme extract was mixed a $50 \mathrm{mM}$ potassium phosphate buffer ( $\mathrm{pH} 7.0$ ) containing $250 \mathrm{mM}$ ascorbate and $1 \mathrm{mM} \mathrm{H}_{2} \mathrm{O}_{2}$. The hydrogen peroxidase (CAT) activity was determined based on the description by McKee et al. (1997). The changes of the absorbance at $240 \mathrm{~nm}$ (an extinction coefficient of $39.4 \mathrm{mM}^{-1} \mathrm{~cm}^{-1}$ ) was monitored after the en-

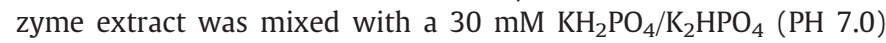
containing $10 \mathrm{mM} \mathrm{H}_{2} \mathrm{O}_{2}$. All measurements were conducted by using the spectrophotometric method.

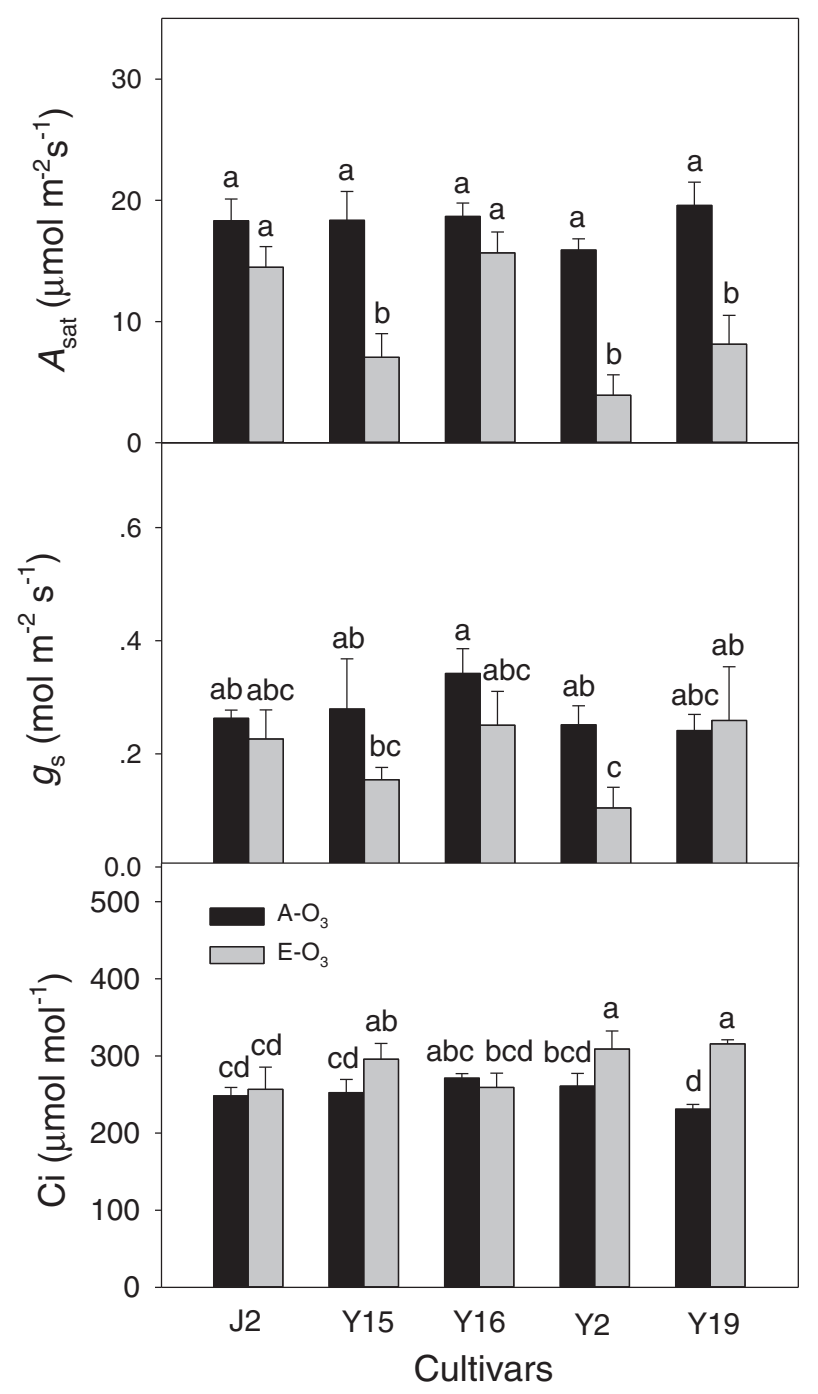

Fig. 1. Light-saturated photosynthesis rate $\left(A_{\text {sat }}\right)$, stomatal conductance $\left(g_{\mathrm{s}}\right)$ and intercellular $\mathrm{CO}_{2}$ concentration $(\mathrm{Ci})$ of winter wheat in the measurement at the midgrain filling stage under ambient $\left[\mathrm{O}_{3}\right]\left(\mathrm{A}-\mathrm{O}_{3}\right)$ and elevated $\left[\mathrm{O}_{3}\right]\left(\mathrm{E}-\mathrm{O}_{3}\right)($ mean $\pm \mathrm{SD}$, $\mathrm{n}=3$ ). The letters on top of the bars are based on the Tukey test across the four measurements. Bars without a same letter are significantly different from each other at $P<0.05$. 


\subsection{Gas exchange, chlorophyll a fluorescence and leaf pigment content}

An in vitro measurement of the gas exchange and fluorescence was carried out following the method of a preceding study (Morgan et al., 2004), as described previously (Feng et al., 2011). Three fully expanded flag leaves of each cultivar per ring were randomly selected. The stems attached with flag leaves were cut under water at predawn and immediately transported to laboratory in low light (PPFD $<20 \mu \mathrm{mol} \mathrm{m} \mathrm{m}^{-2} \mathrm{~s}^{-1}$ ). The measurement was then initiated after light acclimation at $400 \mu \mathrm{mol} \mathrm{m}{ }^{-2} \mathrm{~s}^{-1}$ outside the gas exchange chamber. The LI-6400 photosynthesis system mounted with a 6400-40 leaf chamber fluorometer (LICOR, Lincoln, NE, USA) was employed to measure the gas exchange and fluorescence. The net $\mathrm{CO}_{2}$ assimilation rate vs. intercellular $\mathrm{CO}_{2}$ concentration $(\mathrm{A}-\mathrm{Ci})$ and $\mathrm{A}$ vs. photosynthetic photon flux density (APPFD) curves were determined in two of the fully expanded flag leaves for each cultivar per subplot. $V_{\mathrm{cmax}}, J_{\max }$ and $L_{\mathrm{s}}$ were determined according to the method of Farquhar and Sharkey (1982) from the A-Ci curve, as described previously by Long and Bernacchi (2003). The apparent quantum efficiency (AQY) was estimated from the initial slope of APPFD curve fitted with a linear function (Morgan et al., 2004) and $A_{\text {sat }}$ was from the entire A-PPFD curve fitted with a nonrectangular empirical function (Long and Drake, 1991). The measurement of modulated chlorophyll fluorescence was conducted simultaneously with steadystate (Fs) and maximal ( $\mathrm{Fm}^{\prime}$ ) fluorescence being automatically logged along with the measurement of A-PPFD curve. The actual photochemical efficiency of PSII in the saturated light $\left(\mathrm{Fv}^{\prime} / \mathrm{Fm}^{\prime}\right)$, quenching of photochemical efficiency of PSII ( $q \mathrm{P})$, and the quantum yield of non-cyclic electron transport (PhiPSII) were provided by the software in the instrument.

After gas exchange and chlorophyll $a$ florescence measurements, leaf photosynthetic pigment content was determined spectrophotometrically following the protocol of Lichtenthaler (1987) with the extracts in $95 \%$ ethanol in the dark at $4{ }^{\circ} \mathrm{C}$ for $72 \mathrm{~h}$.

\subsection{Statistics}

The experiment was laid out in a split plot design with the main plot being allocated to the $\left[\mathrm{O}_{3}\right]$ treatment and the subplot being cultivar.
Statistical analysis was conducted based on subplot means for all variables in JMP software (SAS Institute, USA). Analysis of variance (ANOVA) for each variable was performed in a mixed linear model with main plot as a random effect and $\left[\mathrm{O}_{3}\right]$, cultivar and sampling date as fixed effects. Tukey-Kramer HSD test was used for the comparison of variables between $\mathrm{A}-\mathrm{O}_{3}$ and $\mathrm{E}-\mathrm{O}_{3}$. All the data were presented as mean \pm standard deviation of three rings replicates with significance level set at $P \leq 0.05$.

\section{Result}

Across all measurements, $\mathrm{E}-\mathrm{O}_{3}$ had no significant effects on all investigated variables (Tables $1 \& 2$ ). However, significant interaction between $\mathrm{O}_{3}$ and measurement dates was found in most variables excluding POD, SOD, GSH and phenolics, indicating that effects of E- $\mathrm{O}_{3}$ depends on growing stages. Similarly, the responses to $\mathrm{E}-\mathrm{O}_{3}$ among cultivars also depended on growing stages, as indicated by no significant interaction between $\mathrm{O}_{3}$ and cultivar but significant interaction of $\mathrm{O}_{3}$, cultivar and measurement dates for most variables (Tables 1 \& 2). Before the last measurement date, no statistically significant difference was detected between wheat plants exposed to $\mathrm{A}-\mathrm{O}_{3}$ and $\mathrm{E}-\mathrm{O}_{3}$ for any of the physiological variables except the total chlorophyll and carotenoids content (data not shown). Therefore, we present only the results from the final measurement, i.e. mid grain filling stage.

Figs. 1-3 show the photosynthetic responses of each cultivar to $\mathrm{E}-\mathrm{O}_{3}$. Except $g_{s}$, the interactions between cultivar and $\mathrm{O}_{3}$ were statistically significant and most of the photosynthetic parameters showed the varietal differences. Averaged across the five cultivars, $A_{\text {sat }}$ was reduced by $46 \%$ for plants grown at $\mathrm{E}-\mathrm{O}_{3}$, and the $\mathrm{E}-\mathrm{O}_{3}$-induced loss reached statistically significant levels inY19 (58\%), Y2 (78\%) and Y15 (62\%), but not in J2 (21\%) or Y16 (16\%) (Fig. 1). In parallel with the decrease in $A_{\text {sat }}$ by E$\mathrm{O}_{3}, g_{\mathrm{s}}$ showed a similar declining trend inY19, Y2 and Y15, while $\mathrm{Ci}$ and $L_{\mathrm{s}}$ generally increased at $\mathrm{E}-\mathrm{O}_{3}$ for all cultivars (Fig. 1-2). E- $\mathrm{O}_{3}$ significantly reduced $V_{\mathrm{cmax}}$ and $J_{\max }$ with a larger decrease in $V_{\mathrm{cmax}}$, especially in Y19, Y2 and Y15 (Fig. 2). The same was the case for parameters related to fluorescence such as Fv'/Fm', $q \mathrm{P}$, PhiPS2 and AQY (Fig. 3), which showed $\mathrm{E}^{-} \mathrm{O}_{3}$-induced reductions being significant in $\mathrm{Y} 19, \mathrm{Y} 2$ and $\mathrm{Y} 15$ only.

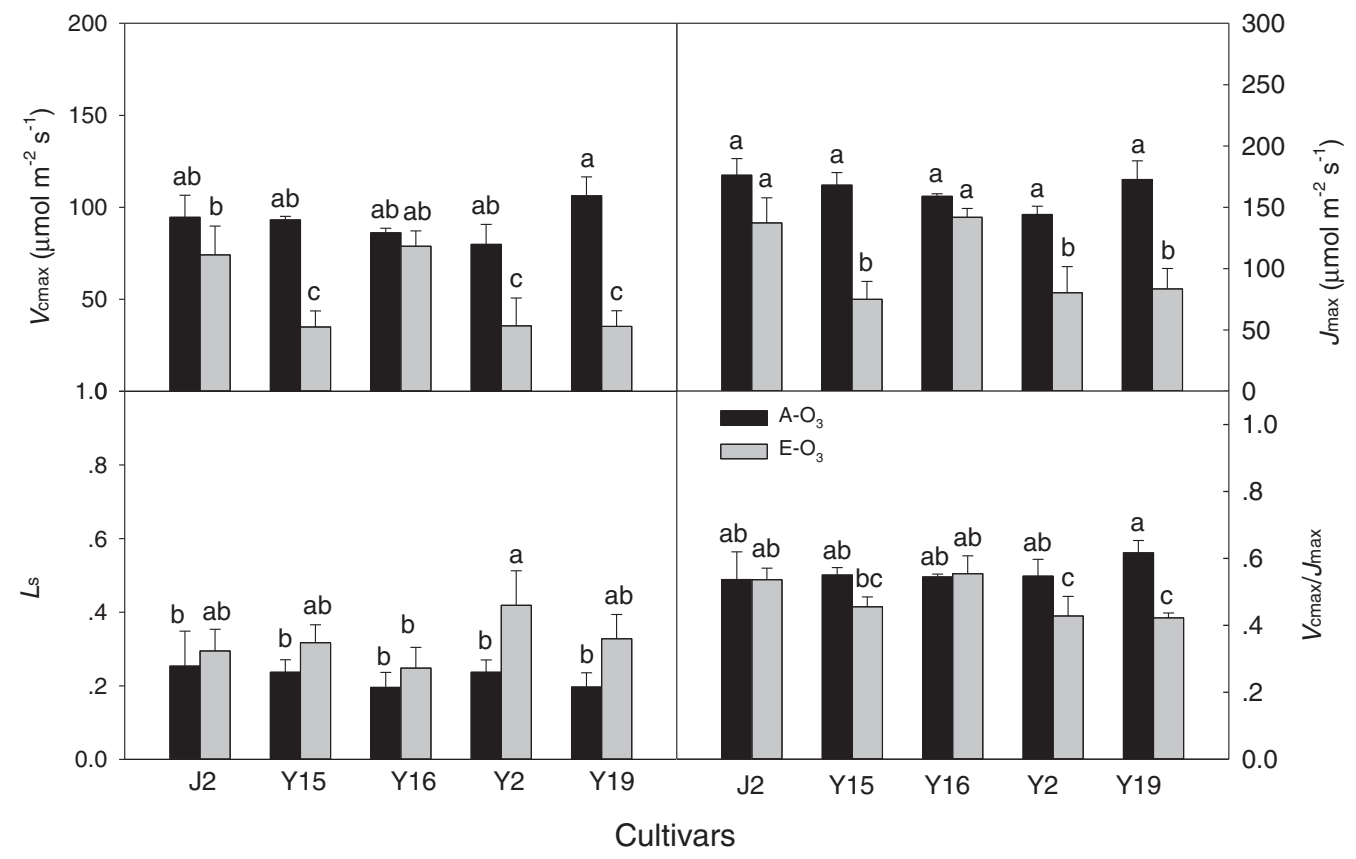

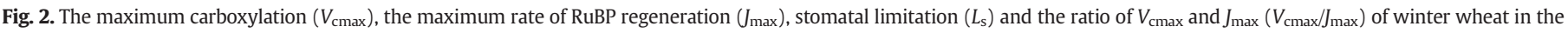

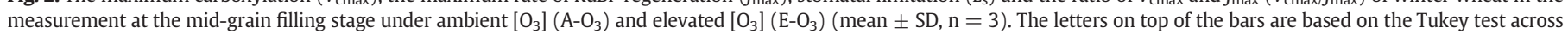
the four measurements. Bars without a same letter are significantly different from each other at $P<0.05$. 


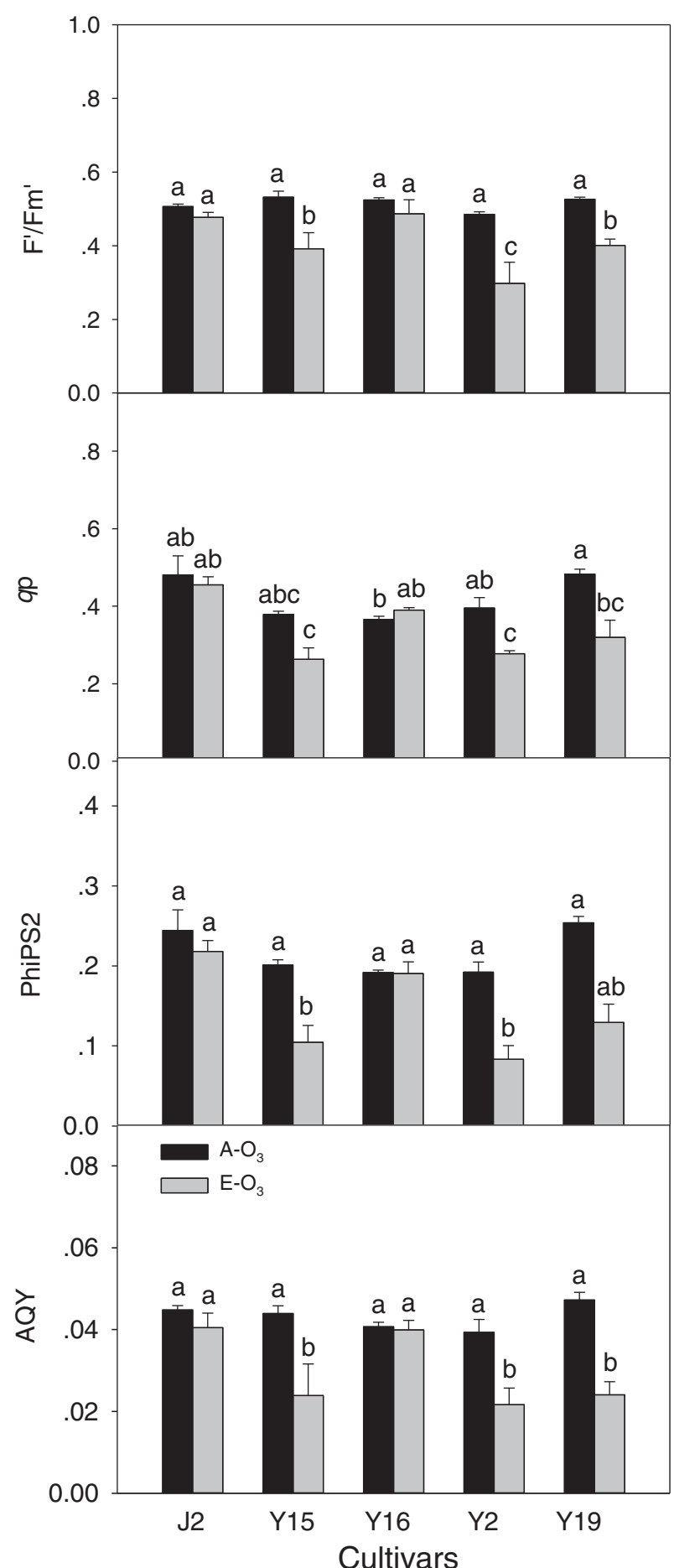

Fig. 3. The actual photochemical efficiency of PSII in the saturated light $\left(\mathrm{Fv}^{\prime} / \mathrm{Fm}^{\prime}\right)$, quenching of photochemical efficiency of PSII $(q \mathrm{P})$, and the quantum yield of non-cyclic electron transport (PhiPSII) and apparent quantum efficiency $\left(\mathrm{PhiCO}_{2}\right)$ of winter wheat in the measurement at the mid-grain filling stage under ambient $\left[\mathrm{O}_{3}\right]\left(\mathrm{A}-\mathrm{O}_{3}\right)$ and elevated $\left[\mathrm{O}_{3}\right]\left(\mathrm{E}^{-} \mathrm{O}_{3}\right)$ (mean $\pm \mathrm{SD}, \mathrm{n}=3$ ). The letters on top of the bars are based on the Tukey test across the four measurements. Bars without a same letter are significantly different from each other at $P<0.05$.

Leaf senescence was significantly accelerated in Y19, Y2 and Y15 at $\mathrm{E}-\mathrm{O}_{3}$, as indicated by significant difference compared with at $\mathrm{A}-\mathrm{O}_{3}$ in chlorophyll, carotenoids and MDA contents (Figs. 4-5). E- $\mathrm{O}_{3}$ did not significantly influence the antioxidant pools including GSH and Phenolics at the last measurement date, but a significant decrease in AsA in Y19 was found (Fig. 5). Among the antioxidant enzymes, APX and POD did not respond to $\mathrm{E}-\mathrm{O}_{3}$ for any of the five cultivars, whereas CAT (Y19 and $\mathrm{Y} 2$ ) as well as SOD (Y2) showed reductions by E-O 3 (Fig. 6).

\section{Discussion}

It has been reported that modern wheat cultivars are more sensitive to $\mathrm{O}_{3}$ than old accessions due to higher $g_{s}$ and lower levels of antioxidant capacity (Pleijel et al., 2006), and that they are subjected to larger oxidative damages to proteins and cellular membranes (Biswas et al., 2008). In this study, five modern cultivars showed variable reduction of $A_{\text {sat }}$ at mid-grain filling stage with a wide range from $16 \%$ to $78 \%$ when exposed to an elevation of average $8 \mathrm{~h}-\left[\mathrm{O}_{3}\right](9: 00-17: 00)$ from $44.4 \mathrm{ppb}$ to $56.4 \mathrm{ppb}$ (Feng et al., 2011), which suggests the presence of intraspecific variation in the response to elevated $\left[\mathrm{O}_{3}\right]$. However, the varietal difference in response to $\mathrm{E}-\mathrm{O}_{3}$ was observed only at the latest developmental stage (mid-grain filling), implying accumulative $\mathrm{O}_{3}$ effects. It is consistent with previous chamber studies of wheat plants (Feng et al., 2008), as well as with SoyFACE experiments using ten soybean cultivars (Betzelberger et al., 2010). At the final measurement stage, $\mathrm{O}_{3}$-induced reduction of $A_{\text {sat }}$ was significant in Y19, Y2 and Y15 but not in J2 and Y16 (Fig. 1), indicating that J2 and Y16 were the least sensitive cultivar followed by Y15, while Y2 and Y19 were the most sensitive ones to $\mathrm{O}_{3}$. This is consistent with the $\mathrm{O}_{3}$-induced grain yield losses in the same cultivars: $13.1 \%$ in J2 as averaged across the years 2008-2010 (unpublished data), and 15.3\% in Y15, 17.7\% in Y16, 24.2\% in Y2 and 20.1\% in Y19 on average across the years 2007-2009 (Zhu et al., 2011).

The sensitivity of plants to $\mathrm{O}_{3}$ has been linked to $\mathrm{O}_{3}$ flux controlled by stomata (Dizengremel et al., 2009; Fiscus et al., 2005) and antioxidant capacity determined by antioxidant pools and enzymes (Biswas et al., 2008; Feng et al., 2010; Inada et al., 2012; Li et al., 2016; Wang et al., 2014a, 2014b). However, there was no significant interaction between cultivar and $\mathrm{O}_{3}$ in $g_{\mathrm{s}}$ across the four measurements (Table 1, Fig.

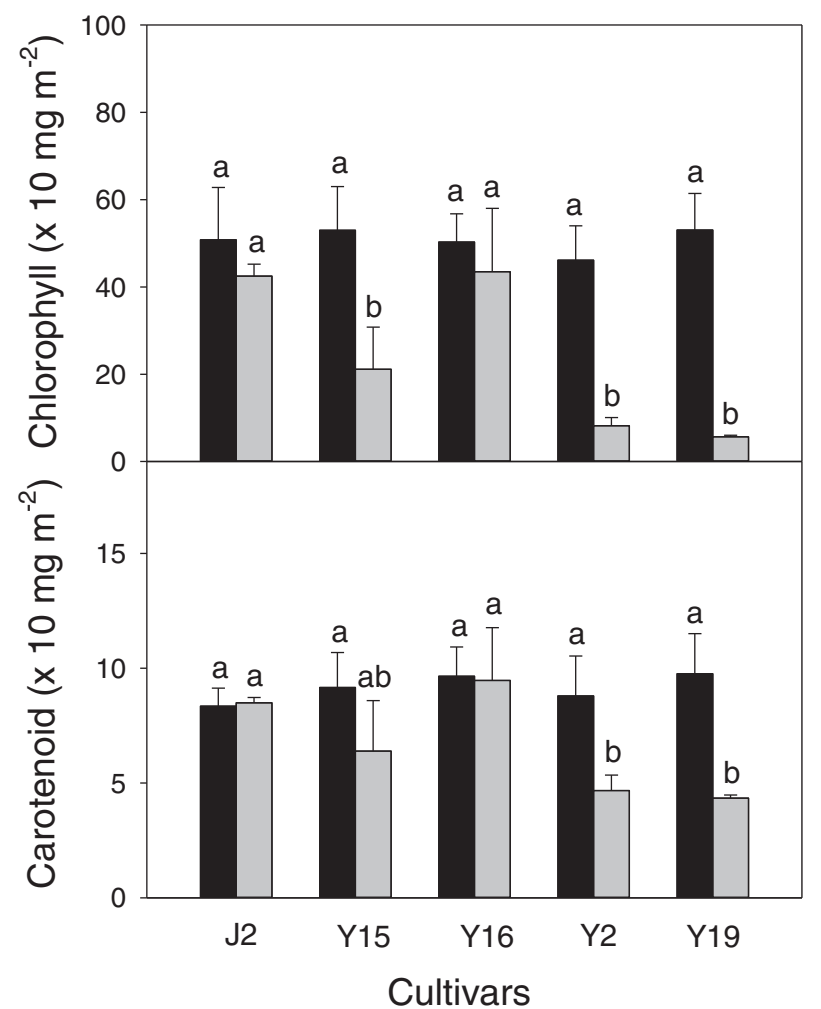

Fig. 4. The chlorophyll and carotenoid contents of winter wheat in the measurement at the mid-grain filling stage under ambient $\left[\mathrm{O}_{3}\right]\left(\mathrm{A}-\mathrm{O}_{3}\right)$ and elevated $\left[\mathrm{O}_{3}\right]\left(\mathrm{E}-\mathrm{O}_{3}\right)($ mean $\pm \mathrm{SD}$ $\mathrm{n}=3$ ). The letters on top of the bars are based on the Tukey test across the four measurements. Bars without a same letter are significantly different from each other at $P<0.05$. 


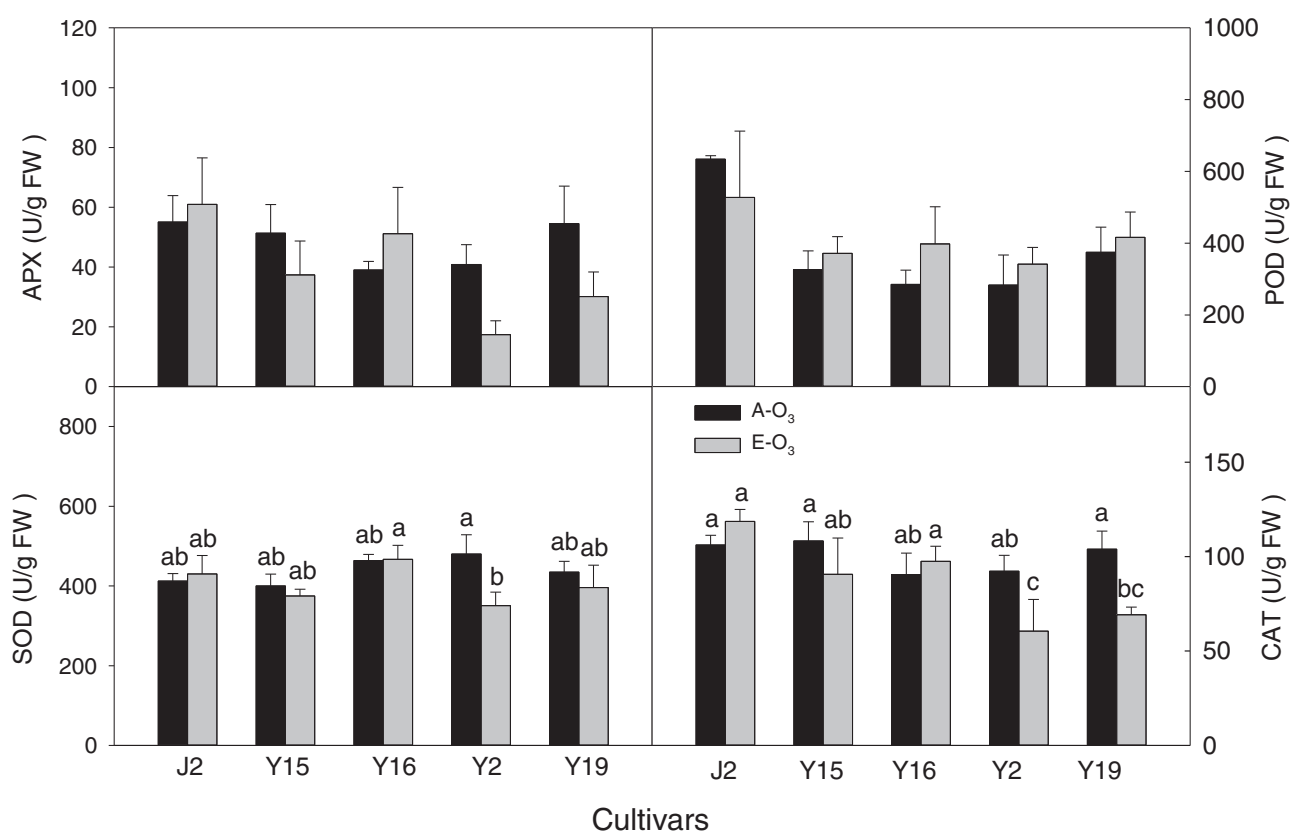

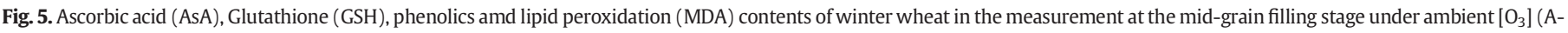

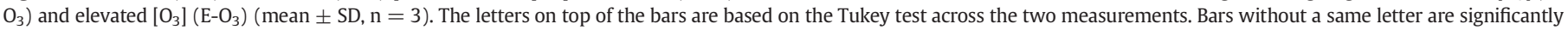
different from each other at $P<0.05$.

1 ), suggesting that $g_{s}$ does not contribute to the significant difference among cultivars in response to $\mathrm{E}-\mathrm{O}_{3}$. Similar results were also found in the study of Y16 and Y2 sensitivity to $\mathrm{O}_{3}$ in terms of photosynthesis (Feng et al., 2011). Therefore, $\mathrm{O}_{3}$-induced reduction in $A_{\text {sat }}$ would be largely attributed to non-stomatal factors, i.e. impaired physiological activity of mesophyll cells (Akhtar et al., 2010; Biswas et al., 2008; Farage and Long, 1999). Further evidence was the increased $\mathrm{Ci}$ (Fig. 1) and decreased Rubisco activity as indicated by $V_{\mathrm{cmax}}$ (Fig.2). For instance, the larger losses in $V_{\text {cmax }}$ and $J_{\max }$ at the final measurement stage for Y19, Y2 and Y15 (Fig.2) suggested that both the Rubisco activity and RuBP (1,5-bisphosphate) regeneration contributed to the reduction of $A_{\text {sat }}$. The larger decline in $V_{c \max }$ compared to $J_{\max }\left(V_{\mathrm{cmax}} / J_{\max }\right)$ of $\mathrm{Y} 19$ underlined the paramount importance of the Rubisco linked photochemical reactions among the non-stomatal factors. This view is supported by previous wheat studies that the greater reduction in $A_{\text {sat }}$ in $\mathrm{E}-\mathrm{O}_{3}$ was related to a reduction of Rubisco activity (Farage and Long,

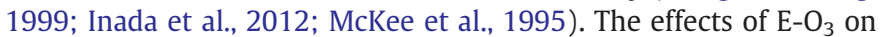
photoinhibition was significant for Y19, Y2 and Y15 at the final measurement date as represented by reduced AQY (Fig. 3), leading to decrease in qP and PhiPS2 (Fig. 3) (Morgan et al., 2004). This may be

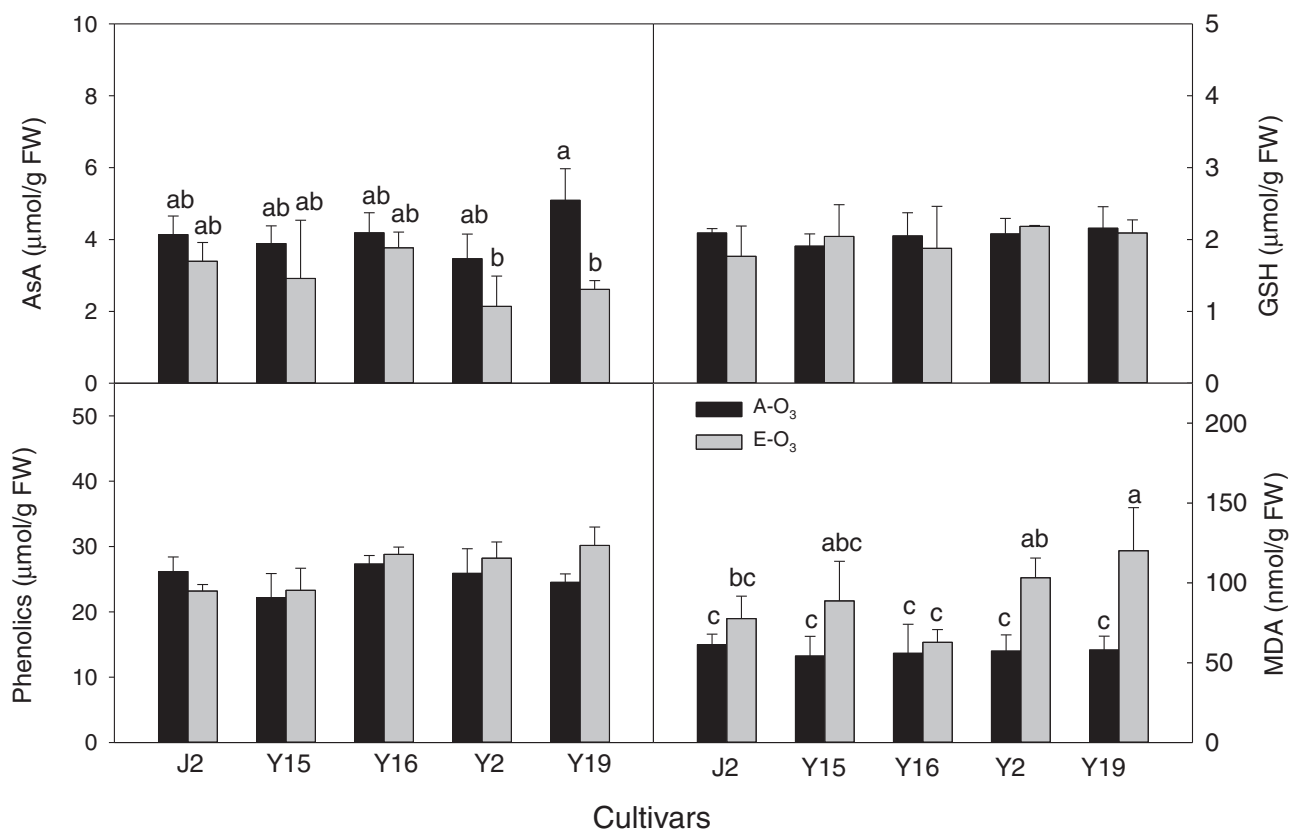

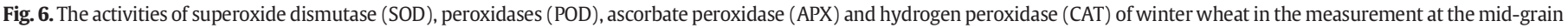

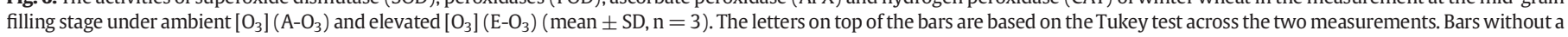
same letter are significantly different from each other at $P<0.05$. 
caused by the lower efficiency of excitation energy captured by open PSII reaction center as indicated by the decrease in $\mathrm{Fv}^{\prime} / \mathrm{Fm}^{\prime}$ (Fig. 3). The reduced quantum yield of PSII electron transport appears to be another non-stomatal factor responsible for the genetic difference among the cultivars. Therefore, the larger decline of $g_{\mathrm{s}}$ and increase of $L_{\mathrm{s}}$ in Y19, $\mathrm{Y} 2$ and $\mathrm{Y} 15$ were the result rather than the cause of the $\mathrm{O}_{3}$-induced $A_{\text {sat, }}$, which is also supported by previous chamber studies (Fiscus et al., 1997; McKee et al., 1995).

Among all antioxidant variables tested in this study, APX, POD, SOD, GSH, Phenolics and AsA showed significant difference among cultivars $(P<0.05)$. Ozone-induced reduction of $A_{\text {sat }}$ in Y19, Y2 and Y15 also resulted from a larger damage to the integrity of chloroplast membrane since greater chlorophyll degradation and lipid peroxidation were observed as indicated by decreased total chlorophyll (Fig. 4) and increased MDA (Fig. 5), respectively. The reduction in $A_{\text {sat, }}$ chlorophyll degradation and lipid peroxidation in turn may lead to accelerated leaf senescence (Fangmeier et al., 1994; Mulholland et al., 1997; Pell et al., 1994), which has been widely reported for many species including wheat as a typical physiological symptom induced by elevated $\mathrm{O}_{3}$ (Feng et al., 2011; Finnan et al., 1998; Miller et al., 1999; Pell et al., 1994; Ribas et al., 2005). Among foliar pigments, carotenoids play an important role in photosynthetic reaction centra by both participating the process of energy-transfer and providing a mechanism for plant photoprotection against photooxidation (Davies, 2004). Therefore, the $\mathrm{O}_{3}$-induced decline in carotenoids similar to that in total chlorophyll at the final measurement underlines the relations between wheat $\mathrm{O}_{3}$ sensitivity and the antioxidant capacity determined by different antioxidant pools including AsA, carotenoids, and enzymes of APX, SOD, CAT and POD. The antioxidants of the apoplast have been reported as the first line of defense against $\mathrm{O}_{3}$ damage (Baier et al., 2005), and the antioxidant metabolism in the leaf tissues acts as a mechanism replenishing antioxidants oxidized by $\mathrm{O}_{3}$ in the apoplast. The insignificant responses of all the tested antioxidant pools and enzymes to $\mathrm{E}^{-} \mathrm{O}_{3}$ for $\mathrm{J} 2, \mathrm{Y} 16$ and/ or Y15 in leaf tissues indicated the antioxidant systems may prevent oxidative damage better than $\mathrm{Y} 19$ and $\mathrm{Y} 2$. Larger $\mathrm{O}_{3}$-induced loss of AsA in Y19, SOD in Y2 and CAT in both Y2 and Y19 resulted in the increasing membrane lipid peroxidation, and thus greater loss in $A_{\mathrm{sat}}$ and yield. These results were supported by the previous wheat FACE studies that Y16 exhibited higher photosynthetic rates (Feng et al., 2011) and apoplastic ascorbate contents (AsA) than Y2 (Feng et al., 2010), and lower levels of ROS and higher apoplastic antioxidant enzyme activities than Y19 (Wang et al., 2014a).

\section{Conclusions}

This study investigated the ecophysiological responses to elevated $\mathrm{O}_{3}$ among five varieties of winter wheat under fully open air field conditions. The significant $\mathrm{O}_{3}$ effects on most variables were only found during the mid-grain filling stage. Among the tested cultivars, two distinct groups with respect to $\mathrm{O}_{3}$ sensitivity could be discerned: sensitive cultivars (Y15, Y2 and Y19) and tolerant cultivars (J2 and Y16). The lower photosynthetic rates induced by E- $\mathrm{O}_{3}$ were mainly due to non-stomatal factors, e.g. lower maximum carboxylation capacity and electron transport rates. Significant interactions between $\mathrm{O}_{3}$ and cultivar were found in antioxidative enzymes, such as SOD and CAT, but not in stomatal conductance and antioxidant contents, suggesting that antioxidative enzymes significantly contributed to the differential response to $\mathrm{E}-\mathrm{O}_{3}$ among cultivars. Current results implied that in addition to strongly needed reductions in emissions of $\mathrm{O}_{3}$ precursors, breeding plant varieties higher in antioxidative enzymes can become on part the strategy to avoid $\mathrm{O}_{3}$-induced yield loss in crops. Also, the obtained results provide important information for the development of accurate modeling $\mathrm{O}_{3}$ effects on crops, especially with respect to the developmental stage when $\mathrm{O}_{3}$ damage to photosynthesis becomes manifest.

\section{Acknowledgements}

This study has been funded by the Hundred Talents Program, Chinese Academy of Sciences, Fellowship of Japan Society for the Promotion of Science (P09120), the International S \& T Cooperation Program of China (2009DFA31110). We are grateful to Prof. G. Liu and Dr. H. Y. Tang for their technical support in the free-air ozone release system.

\section{References}

Akhtar, N., Yamaguchi, M., Inada, H., Hoshino, D., Kondo, T., Izuta, T., 2010. Effects of ozone on growth, yield and leaf gas exchange rates of two Bangladeshi cultivars of wheat (Triticum aestivum L.). Environ. Pollut. 158, 1763-1767.

Ashmore, M.R., 2005. Assessing the future global impacts of ozone on vegetation. Plant Cell Environ. 28, 949-964.

Baier, M., Kandlbinder, A., Golldack, D., Dietz, K.J., 2005. Oxidative stress and ozone: perception, signalling and response. Plant Cell Environ. 28, 1012-1020.

Betzelberger, A.M., Gillespie, K.M., McGrath, J.M., Koester, R.P., Nelson, R.L., Ainsworth, E.A., 2010. Effects of chronic elevated ozone concentration on antioxidant capacity, photosynthesis and seed yield of 10 soybean cultivars. Plant Cell Environ. 33, 1569-1581.

Biswas, D.K., Xu, H., Li, Y.G., Sun, J.Z., Wang, X.Z., Han, X.G., Jiang, G.M., 2008. Genotypic differences in leaf biochemical, physiological and growth responses to ozone in 20 winter wheat cultivars released over the past 60 years. Glob. Chang. Biol. 14, 46-59.

Booker, F., Muntifering, R., McGrath, M., Burkey, K., Decoteau, D., Fiscus, E., Manning, W., Krupa, S., Chappelka, A., Grantz, D., 2009. The ozone component of global change: potential effects on agricultural and horticultural plant yield, product quality and interactions with invasive species. J. Integr. Plant Biol. 51, 337-351.

Burkart, S., Bender, J., Tarkotta, B., Faust, S., Castagna, A., Ranieri, A., Weigel, H.J., 2013. Effects of ozone on leaf senescence, photochemical efficiency and grain yield in two winter wheat cultivars. J. Agron. Crop Sci. 199, 275-285.

Burkey, K.O., Eason, G., Fiscus, E.L., 2003. Factors that affect leaf extracellular ascorbic acid content and redox status. Physiol. Plant. 117, 51-57.

Bytnerowicz, A., Omasa, K., Paoletti, E., 2007. Integrated effects of air pollution and climate change on forests: a northern hemisphere perspective. Environ. Pollut. 147, 438-445.

Conklin, P.L., Barth, C., 2004. Ascorbic acid, a familiar small molecule intertwined in the response of plants to ozone, pathogens, and the onset of senescence. Plant Cell Environ. 27, 959-970.

Davies, K., 2004. Plant pigments and their manupulation. Annu Plant Rev 14, 57-91.

Dizengremel, P., Le Thiec, D., Bagard, M., Jolivet, Y., 2008. Ozone risk assessment for plants: central role of metabolism-dependent changes in reducing power. Environ. Pollut. 156, 11-15

Dizengremel, P., Le Thiec, D., Hasenfratz-Sauder, M.P., Vaultier, M.N., Bagard, M., Jolivet, Y., 2009. Metabolic-dependent changes in plant cell redox power after ozone exposure. Plant Biol. 11, 35-42.

Fangmeier, A., Brunschon, S., Jager, H.J., 1994. Time course of oxidant stress biomarkers in flag leaves of wheat exposed to ozone and drought stress. New Phytol. 126, 63-69.

Farage, P.K., Long, S.P., 1999. The effects of $\mathrm{O}_{3}$ fumigation during leaf development on photosynthesis of wheat and pea: an in vivo analysis. Photosynth. Res. 59, 1-7.

Farquhar, G.D., Sharkey, T.D., 1982. Stomatal conductance and photosynthesis. Annu. Rev. Plant Physiol. Plant Mol. Biol. 33, 317-345.

Feng, Z.Z., Kobayashi, K., 2009. Assessing the impacts of current and future concentrations of surface ozone on crop yield with meta-analysis. Atmos. Environ. 43, 1510-1519.

Feng, Z.Z., Kobayashi, K., Ainsworth, E.A., 2008. Impact of elevated ozone concentration on growth, physiology, and yield of wheat (Triticum aestivum L.): a meta-analysis. Glob. Chang. Biol. 14, 2696-2708.

Feng, Z.Z., Pang, J., Kobayashi, K., Zhu, J., Ort, D.R., 2011. Differential responses in two varieties of winter wheat to elevated ozone concentration under fully open-air field conditions. Glob. Chang. Biol. 17, 580-591.

Feng, Z.Z., Pang, J., Nouchi, I., Kobayashi, K., Yamakawa, T., Zhu, J., 2010. Apoplastic ascorbate contributes to the differential ozone sensitivity in two varieties of winter wheat under fully open-air field conditions. Environ. Pollut. 158, 3539-3545.

Feng, Z.Z., Paoletti, E., Bytnerowicz, A., Harmons, H., 2015. Ozone and plants. Environ. Pollut. 202, 215-216.

Feng, Z.Z., Sun, J., Wan, W., Hu, E., Calatayud, V., 2014. Evidence of widespread ozone-induced visible injury on plants in Beijing, China. Environ. Pollut. 193, 296-301.

Finnan, J.M., Jones, M.B., Burke, J.I., 1998. A time-concentration study on the effects of ozone on spring wheat (Triticum aestivum L.). 3: effects on leaf area and flag leaf senescence. Agric. Ecosyst. Environ. 69, 27-35.

Fiscus, E.L., Booker, F.L., Burkey, K.O., 2005. Crop responses to ozone: uptake, modes of action, carbon assimilation and partitioning. Plant Cell Environ. 28, 997-1011.

Fiscus, E.L., Reid, C.D., Miller, J.E., Heagle, A.S., 1997. Elevated $\mathrm{CO}_{2}$ reduces $\mathrm{O}_{3}$ flux and $\mathrm{O}_{3}-$ induced yield losses in soybeans: possible implications for elevated $\mathrm{CO}_{2}$ studies. J. Exp. Bot. 48, 307-313.

Gelang, J., Pleijel, H., Sild, E., Danielsson, H., Younis, S., Sellden, G., 2000. Rate and duration of grain filling in relation to flag leaf senescence and grain yield in spring wheat (Triticum aestivum) exposed to different concentrations of ozone. Physiol. Plant 110, 366-375.

Gillespie, K.M., Rogers, A., Ainsworth, E.A., 2011. Growth at elevated ozone or elevated carbon dioxide concentration alters antioxidant capacity and response to acute oxidative stress in soybean (Glycine max). J. Exp. Bot. 62, 2667-2678.

Gillespie, K.M., Xu, F., Richter, K.T., McGrath, J.M., Markelz, R.J.C., Ort, D.R., Leakey, A.D.B. Ainsworth, E.A., 2012. Greater antioxidant and respiratory metabolism in field- 
grown soybean exposed to elevated $\mathrm{O}_{3}$ under both ambient and elevated $\mathrm{CO}_{2}$. Plant Cell Environ. 35, 169-184.

Griffith, O.W., 1980. Determination of glutathione and glutathione disulfide using glutathione reductase and 2-vinylpyridine. Anal. Biochem. 106, 207-212.

Heath, R.L., Packer, L., 1968. Photoperoxidation in isolated chloroplasts. I. Kinetics and stoichiometry of fatty acid peroxidation. Arch. Biochem. Biophys. 125, 189-198.

Inada, H., Kondo, T., Akhtar, N., Hoshino, D., Yamaguchi, M., Izuta, T., 2012. Relationship between cultivar difference in the sensitivity of net photosynthesis to ozone and reactive oxygen species scavenging system in Japanese winter wheat (Triticum aestivum). Physiol. Plant. 146, 217-227.

Kangasjarvi, J., Jaspers, P., Kollist, H., 2005. Signalling and cell death in ozone-exposed plants. Plant Cell Environ. 28, 1021-1036.

Kangasjarvi, J., Talvinen, J., Utriainen, M., Karjalainen, R., 1994. Plant defense systmes induced by ozone. Plant Cell Environ. 17, 783-794.

Kollist, H., Moldau, H., Mortensen, L., Rasmussen, S.K., Jorgensen, L.B., 2000. Ozone flux to plasmalemma in barley and wheat is controlled by stomata rather than by direct reaction of ozone with cell wall ascorbate. J. Plant Physiol. 156, 645-651.

Li, P., Calatayud, V., Gao, F., Uddling, J., Feng, Z., 2016. Differences in ozone sensitivity among woody species are related to leaf morphology and antioxidant levels. Tree Physiol. http://dx.doi.org/10.1093/treephys/tpw042.

Lichtenthaler, H.K., 1987. Chlorophylls and carotenoids: pigments of photosynthetic biomembranes. Methods Enzymol. 148, 350-382.

Long, S.P., Bernacchi, C.J., 2003. Gas exchange measurements, what can they tell us about the underlying limitations to photosynthesis? Procedures and sources of error. J. Exp. Bot. 54, 2393-2401.

Long, S.P., Drake, B.G., 1991. Effect of the long-term elevation of $\mathrm{CO}_{2}$ concentration in the field on the quantum yield of photosynthesis of the $\mathrm{C} 3$ sedge, Scirpus olneyi. Plant Physiol. 96, 221-226.

Luwe, M., Heber, U., 1995. Ozone detoxification inthe apoplasm and symplasm of spinach, board bean and beech leaves at ambient and elevated concentrations of ozone in air. Planta 197, 448-455.

McKee, I.F., Eiblmeier, M., Polle, A., 1997. Enhanced ozone-tolerance in wheat grown at an elevated $\mathrm{CO}_{2}$ concentration: ozone exclusion and detoxification. New Phytol. 137, 275-284.

McKee, I.F., Farage, P.K., Long, S.P., 1995. The interactive effects of elevated $\mathrm{CO}_{2}$ and $\mathrm{O}_{3}$ concentration on photostnthesis in spring wheat. Photosynth. Res. 45, 111-119.

Miller, J.D., Arteca, R.N., Pell, E.J., 1999. Senescence-associated gene expression during ozone-induced leaf senescence in Arabidopsis. Plant Physiol. 120, 1015-1023.

Morgan, P.B., Bernacchi, C.J., Ort, D.R., Long, S.P., 2004. An in vivo analysis of the effect of season-long open-air elevation of ozone to anticipated 2050 levels on photosynthesis in soybean. Plant Physiol. (135), 2348-2357.
Mulholland, B.J., Craigon, J., Black, C.R., Colls, J. Atherton, J., Landon, G., 1997. Impact of elevated atmospheric $\mathrm{CO}_{2}$ and $\mathrm{O}_{3}$ on gas exchange and chlorophyll content in spring wheat (Triticum aestivum L.). J. Exp. Bot. 48, 1853-1863.

Overmyer, K., Brosche, M., Kangasjarvi, J., 2003. Reactive oxygen species and hormonal control of cell death. Trends Plant Sci. 8, 335-342.

Paoletti, E., Ranieri, A., Lauteri, M., 2008. Moving toward effective ozone flux assessment. Environ. Pollut. 156, 16-19.

Pell, E.J., Eckardt, N.A., Glick, R.E., 1994. Biochemical and molecular basis for impairment of photosynthetic potential. Photosynth. Res. 39, 453-462.

Pleijel, H., Danielsson, H., Gelang, J., Sild, E., Sellden, G., 1998. Growth stage dependence of the grain yield response to ozone in spring wheat (Triticum aestivum L.). Agric. Ecosyst. Environ. 70, 61-68.

Pleijel, H., Eriksen, A.B., Danielsson, H., Bondesson, N., Sellden, G., 2006. Differential ozone sensitivity in an old and a modem Swedish wheat cultivar - grain yield and quality, leaf chlorophyll and stomatal conductance. Environ. Exp. Bot. 56, 63-71.

Rao, M.V., Koch, J.R., Davis, K.R., 2000. Ozone: a tool for probing programmed cell death in plants. Plant Mol. Biol. 44, 345-358.

Ribas, A., Penuelas, J., Elvira, S., Gimeno, B.S., 2005. Ozone exposure induces the activation of leaf senescence-related processes and morphological and growth changes in seedlings of Mediterranean tree species. Environ. Pollut. 134, 291-300.

Singleton, V.L., Rossi, J.A., 1965. Colorimetry of total phenolics with phosphomolybdicphosphotungstic acid reagents. Am. J. Enol. Vitic. 16, 144-158.

Sun, J., Feng, Z., Ort, D.R., 2014. Impacts of rising tropospheric ozone on photosynthesis and metabolite levels on field grown soybean. Plant Sci. 226, 147-161.

Tang, H., Liu, G., Han, Y., Zhu, J., Kobayashi, K., 2011. A system for free-air ozone concentration elevation with rice and wheat: control performance and ozone exposure regime. Atmos. Environ. 45, 6276-6282.

Van Dingenen, R., Dentener, F.J., Raes, F., Krol, M.C., Emberson, L., Cofala, J., 2009. The global impact of ozone on agricultural crop yields under current and future air quality legislation. Atmos. Environ. 43, 604-618.

Wang, J., Zeng, Q., Zhu, J., Chen, C., Liu, G., Tang, H., 2014a. Apoplastic antioxidant enzyme responses to chronic free-air ozone exposure in two different ozone-sensitive wheat cultivars. Plant Physiol. Biochem. 82, 183-193.

Wang, J., Zhu, J., Zeng, Q., Liu, G., 2014b. Phenolic compounds and antioxidant ability responses to experimental free-air ozone exposure in two wheat cultivars. B Environ Contam Tox 93, 625-631.

Zheng, Y., Shimizu, H., Barnes, J.D., 2002. Limitations to $\mathrm{CO}_{2}$ assimilation in ozone-exposed leaves of Plantago major. New Phytol. 155, 67-78.

Zhu, X., Feng, Z., Sun, T., Liu, X., Tang, H., Zhu, J., Guo, W., Kobayashi, K., 2011. Effects of elevated ozone concentration on yield of four Chinese cultivars of winter wheat under fully open-air field conditions. Glob. Chang. Biol. 17, 2697-2706. 